K A N D A I

\begin{tabular}{|l|l|l|}
\hline Volume 17 & No. 2, November 2021 & Halaman 166-176 \\
\hline
\end{tabular}

\title{
THE USE OF INDONESIAN LOAN WORDS IN MUNA LANGUAGE (Penggunaan Kata-Kata Serapan Bahasa Indonesia dalam Bahasa Muna)
}

\author{
La Aso \& La Yani Konisi \\ Department of Language and Literature, Cultural Faculty \\ of Halu Oleo University, \\ Kendari. Indonesia \\ Pos-el: la_aso@yahoo.co.id
}

(Diterima: 31 Maret 2021; Direvisi: 22 Juli 2021; Disetujui: 18 Agustus 2021)

\begin{abstract}
Abstrak
Artikel ini bertujuan untuk membahas penggunaaan kata-kata serapan bahasa Indonesia dalam bahasa Muna. Data dalam penelitian ini dikumpulkan melalui pengamatan, partisipasi, rekaman, catat, dan interpretasi. Data yang diperoleh kemudian dianalisis secara deskriptif dengan mengklasifikasi data yang dikumpul, menentukan kata-kata serapan, memformulasikan dan menjelaskan kata-kata serapan dan membuat kesimpulan. Hasil penelitian ini menunjukkan bahwa kata-kata serapan bahasa Indonesia dalam bahasa Muna selalu dipengaruhi oleh aspek fonologis atau perubahan bunyi. Karakteristik bahasa Muna sebagai bahasa vokalis menyebabkan semua silabel atau kata-kata pinjaman dari bahasa Indonesia ke bahasa Muna senantiasa menjadi silabel terbuka. Hal itu dapat terjadi melalui berbagai perubahan, seperti penambahan dan penghilangan konsonan, penambahan vokal, dan pemecahan kluster atau gugus konsonan.
\end{abstract}

Kata-kata kunci: kata-kata serapan, bahasa Indonesia, bahasa Muna

\begin{abstract}
This article aims at discussing the use of Indonesian loan words in the Muna language. The data were collected through observation, participation, recording, noting, and interpretation. The data were then analyzed descriptively by classifying the gathered data, indicating the word classes, formulating and describing loan words, and making a conclusion. The result of this study showed that Indonesian loan words in the Muna language are mostly affected by phonological aspects or sound changes. Muna language's characteristics as vocalist language bring all loan words from Indonesian into Muna language always become open syllable. It occurs both by adding or deleting one of the consonants, adding or inserting vocals, and breaking cluster or consonant cluster.
\end{abstract}

Keywords: loan words, Indonesian language, Muna language

DOI: 10.26499/jk.v17i2.3481

How to cite: Aso, L. \& Konisi, L. Y. (2021). The use of Indonesian loan words in Muna language. Kandai, 17(2), 166-176 (DOI: 10.26499/jk.v17i2.3481)

\section{INTRODUCTION}

In communication, there is a marked system that is agreed by the people who communicate. The marked system has the same value and reference to the people who have a communication process. Language as the communication tool will convey ideas or opinions stated through the relation unity of the relation variation from the symbol's system that the speaker and the interlocutor had together. 
One of the language types which has unique and exciting character is the local language. Local language has a significant function to establish national language and culture. Local language users can develop and reserve them well, as local languages are a treasure of national language and culture. Local languages are expected to guide and improve the local languages generally. This case is in line with Irmawati's statement (2004) that the local language functions as a proud symbol of an area, an identity symbol, and a connection tool of local society's cultural establishment. The local language functions are related to the growth, development, and standardization of local language on establishing, developing, and standardizing local languages in Indonesia. Therefore, local languages should be maintained, preserved, and improved to enrich the Indonesian language, particularly in vocabulary aspects and heterogeneity of national culture.

Muna language is one of the local languages in Southeast Sulawesi, Indonesia. Although it exists in Muna and West Muna regencies, it is also spoken in several Southeast Sulawesi regencies such as Buton, Wakatobi, Konawe, and Kendari. In other words, the speech community of the Muna language spread out around Southeast Sulawesi, particularly in Kendari City.

Van den Berg (1989) divided the Muna language into three dialects; they are Standard Muna dialect, Tiworo Kepulauan dialect, and Gu-Mawasangka dialect. Standard Muna dialect and Tiworo Kepulauan dialect are used in Muna and West Muna regencies, while Gu- Mawasangka dialect exists in the Center of Buton regency. Muna language has specific unique phonemes and phenomena of phoneme changings. One of the exciting phenomena in the
Muna language is changing the phoneme $/ \mathrm{dh} /$ to $/ \mathrm{j} /$ and $/ \mathrm{t} /$ to $/ \mathrm{c} /$ such as the word bhadhu becomes bhaju which means 'shirt' and kaghati becomes kaghaci which means 'kite.' The phenomena of phoneme changes in Muna language like the examples above are often found in Kusambi and Watopute sub-district of Muna regency (Aso, 2006).

Relating to the development of many sectors, information, and technology, the Muna language is still used effectively by the Muna ethnic people, mainly those who live at Muna and West Muna Regency. Likewise, the Munanese community who lives at Kendari still uses the Muna language in their daily communication. Unfortunately, many young generations of Munanese do not use the Muna language consistently. That is why they often combine Indonesian and the Muna languages in their daily communication. Therefore, code-mixing, code-switching, and loan words are often found in Muna people daily communication who live at Kendari. Loan words are one of the interesting phenomena to be investigated because it is unique.

Muna ethnic people often modify Indonesian words into Muna words. They often speak the Muna language by borrowing some linguistic aspects or words from the Indonesian language. For example, The word kapal (boat) in Indonesian is changed into kapala in the Muna language. The word apel (apple) in Indonesian is changed to apele (apple) in the Muna language; the word kulkas (refrigerator) in Indonesian is changed to kulukasi in the Muna language; the word motor (motorcycle) in Indonesian is changed to be motoro in the Muna language. The words such as kapala, apele, kulukasi, and motoro are borrowed from Indonesian language. There are many other examples of loan words from the Indonesian language 
used in the Muna language. In sum, the Muna language is always developing, and it is reached with several loan words from the Indonesian language.

Based on the phenomena and explanation above, it is advantageous to conduct a study about the use of Indonesian loan words in the Muna language. It is expected that the use of Indonesian loan words from the Indonesian language into the Muna language can be described clearly. Nevertheless, this study focuses on using loan words from the Indonesian language into the Muna language in terms of the phonological system. It is more exciting and valuable since the writer is one of the native speakers of the Muna language. The result of this study is expected be able to give a significant contribution to the maintenance and development of the Muna language. Therefore, this study's result is hoped to keep the original words in the Muna language. In other words, they can be recognized which the original words and which the loan words in the Muna language are.

This research is expected to help the development of the Muna language, to enrich the Indonesian language and the culture, to help other researchers who want to conduct a similar study about the Muna language and to support regional language teaching, particularly the Muna language.

\section{THEORETICAL FRAMEWORK}

To support this study's discussion, it needs several concepts and a theoretical framework, about loan words, phonology, and phonetic concepts. Phonology and phonetic concepts are needed to explain the sound changes of loan words. Vervaet (2017) explained that languages are not static entities, on the contrary, they are constantly subject to change. Cultural contact often leads to the exchange of linguistic features and words. This phenomenon is referred to as 'borrowing' and a word of foreign origin is called a 'loanword'. In Oxford Learner's Dictionaries (2017) 'loan word' is defined as "A word adopted from a foreign language with little or no modification".

Loan words are taken or adapted from other languages or dialects and inserted into a particular language. In this study, loan words are taken or adapted from the Indonesian language and inserted into the Muna language. Compbell (1998) stated that word borrowing is adopting words from other languages and the words used in a particular language as a borrower. Robins (1992) also stated that cultural contact will influence language changes, including the existence of loan words. Compbell (1998) added that a particular language usually borrows words from other languages is caused by the need and prestige.

Compbell (1998) argued that when two languages are in contact, it is a normal phenomenon for a less powerful language to incorporate some words from the more powerful language, most of which are those words that denote new concepts, ideas, objects, processes, and phenomena. According to Robbins (1992) borrowers usually adopt loan words based on their language phonology systems. It means that loan words are not arbitrary. The speaker is not free to choose any form or sound of loan words. It is not received freely by the receiver or user of the language. Rather it will be adopted based on the receiver's language system, particularly in phonology, morphology, and linguistic aspects. For example, the word kapala in Muna language is adopted from Indonesian, kapal (boat); batala in Muna language is adopted from 
Indonesian, batal (cancel); and wakutu is adopted from Indonesian, waktu (time).

Each language is signed with sounds, and each language has a specific sound. The sounds of language are studied in phonology. Phonology is divided into the phone, sound, and logy, which means science or knowledge. Chaer (2003; Marsono, 1986) classified sounds in seven ways, they are (1) vowel, consonant, and semi-vowel, (2) nasal and oral, (3) fortes and lanes, (4) long and short sound, (5) single and double sounds, (6) voice and voiceless sounds, and (7) expressive and ingressive sounds.

Apart from phonology phonetics is a study about language sounds. Finegan (2014) defined phonetics as the study of speech sounds in human languages. There are three kinds of phonetics, namely organic phonetics, acoustics phonetics, and auditory phonetics. Organic phonetics studies how speech acts tools systems can create sound. Acoustics phonetics studies the physical form of sound while auditory organic studies how the auditory system receives language sounds. Finegan (2014) stated that there are three principal phonetic branches: (1) articulatory phonetics focuses on the human vowel apparatus and describes articulation sounds in the bowel tract;(2) acoustics phonetics uses physics tools to study the nature of sound waves produced in human language; and (3) auditory phonetics focuses on the perception of sounds by the brain through the human ear. Chaer (2003) also classified the phonetic branches into three parts, they are (1) organics or physiologic, (2) acoustics, and auditory phonetics. Gleason (1961) defined organic phonetics as a study about how the human body's speech organ mechanisms create language sound and Malmberg (1961) defined acoustics phonetics as the study of language sounds of physic symptoms. The last branch, auditory phonetics, is defined as a phonetics study that learns how the hearing mechanism receives language sound as air vibrant (Brosntein $\&$ Beatrice, 1967).

Based on the explanation above, it can be concluded that phonetics is a study of how the human being creates sounds, how the ear receives the sounds, and how physics form the sounds. That is why someone or people can perceive the differences between their language sounds and can identify the words by their typical sound patterns. It is revealed in such phenomena as puns, jokes, and other games. Therefore, talking about phonetics cannot be separated from the existence of speech organs. There are 25 parts of speech organs (Chaer, 2003). However, in essence, there are only 12 parts of the vital speech organ, namely larynx, pharynx, dorsum, medium, aluminum, apex, uvula, velum, palatum, alveolum, dentum, and labium.

In phonology, it is also known as the term of phonemics. Phonemics talks about the phoneme system of a language. The phoneme is the sound unit on which all these contrasts depend is (Finegan, 2014). A phoneme can be classified into two significant parts; they are vowel and consonant sounds. The phoneme is divided into four parts: vowel phoneme, consonant phoneme, diphthong (vowel sequence sounds), and cluster (consonant sequence sounds). Vowel, either short or long vowel sounds, are usually signed by colon symbol (:).

Based on the explanation above, we know or recognize several terms of studying language sound. One states that the sound of human language is studied in phonology and phonetics. Other only covers phonology and divides phonology into two parts, namely phonetics and phonemics. In this case, Chaer (2003) explained the differences between the 
concept of phonemics and phonetics. Phonetics is a branch of phonology that studies speech sound without considering the sound will differentiate meaning or not, while phonemics is a branch of phonology that studies speech sound with considering the sound will differentiate meaning. It means that phonetics and phonemics are two parts of the phonology system. However, other linguists equate the study of phonetics and phonology.

Taembo (2013) conducted a comparative study between Muna and Wakatobi language. In the study, he described the phonology of the Muna language. However, the study of loan words has not been described yet. Aso (2006) further investigated the Muna language's internal innovation and loan words from Indonesian to the Muna language. However, he studied the Muna language in diachronic or historical linguistics, which is different from the present study in which the present study tries to investigate the phonology system changes related to loan words of Indonesian in Muna languages. Van den Berg (1995) investigated Dutch loans in the Muna language. His study focused on the aspects of forestry, injections, and card. In his study, Berg only discussed the semantic domain, phonetic adaptations, semantics shift, grammatical changes, and outstanding loans generally. Related to the phonetic adaptations that have closed relevant to the present study, he did not describe it deeply as investigated in this present study. It involves replacing foreign sounds, avoiding final consonants, breaking the cluster, other idiosyncratic changes, reanalysis, and folketymologies. The present study describes and explains deeply with many examples of vowel adaption, consonant adaption, and phonological changes either in the front, middle, or end of loan words in the
Muna language. The present study gives more explanations and examples of loan words from Indonesian into Muna language.

\section{RESEARCH METHOD}

This study used a descriptive qualitative design. It used descriptive qualitative since the researcher acted as the main instrument who classified and described the real data, and the result of this study is in descriptive form. This study's data were obtained from interview and scrutinize methods (Mahsun, 1995; Sudaryanto, 1993).

Some techniques were applied to collect the data: observation, participation, recording, noting, and introspection. It was classified and then analyzed by using the equivalent method. The researcher participated directly in the conversation with member of people either actively and receptively. The recording was applied to record the language used by the people in their interaction. The researcher needed to transcribe the relevant data which are found in the field. However, the researcher just took a note about Indonesian loan words in the Muna language. After recording and noting, the researcher clarified the obtained data by doing introspection techniques based on the researchers' background knowledge as the native speakers of Muna language.

The data were analyzed descriptively by classifying the gathered data and then indicating the categories or word classes such as nouns, adjectives, and verbs of loan words in the Muna language. The last step done by the researcher is formulating and describing loan words and drawing a conclusion. 


\section{DISCUSSION}

\section{The Use of Indonesian Loan Words in Muna Language}

Based on the field's data, Indonesian loan words (IL) in the Muna language (ML) can be explored and classified as follows.

\section{Deletion of a Sound Cluster/Consonant Sequence}

Consonant $/ \mathrm{k} /$ followed by consonant $/ \mathrm{t} /$ on the middle position

When consonant $/ \mathrm{k} /$ of Indonesian word is in the middle position and followed by phoneme $/ t /$, the consonant $/ \mathrm{k} /$ is deleted in Muna language.

Examples:

- dokter (IL) > dotoro (ML) 'doctor'

- hektare (IL) > heto (ML) 'hectare'

- kondektur (IL) > kondeturu (ML) 'conductor'

- traktir (IL) > taratiri (ML) 'treat'

- praktik (IL) > parateki (ML) 'practice'

- karakter (IL) > karatere (ML) 'character'

The phenomenon occurs because Muna language is a vocalist language and its native speakers are very difficult to pronounce consonant sounds at an opened position or opened syllable. Therefore, native speakers of Muna usually adopt and adapt loan words into Muna sound features. The adaptation is done by breaking the opened syllable to closed syllable either deletion of consonants or addition of vowel. It is similar to the result of Aso's study that Muna's speakers usually adopt and adapt loan words into Muna sound features (Aso, 2006). Related to the addition of vowel, it is adapted to the closed sound feature of a preceded vowel. It lines to the Schane's and Crowley's statements or theories of harmony vowel that one vowel usually assimilated to other vowel features (Crowley, 1992; Schane, 1973). It occurs because the speakers tend to easier to pronounce it if the vowels in one word have similar or rather similar sound features.

\section{Consonant $/ y /$ between consonant and} vowel or between vowel and vowel

When consonant /y/ in Indonesian word is on the position between consonant and vowel or between vowel and vowel, the consonant / $\mathrm{y} /$ in Muna language is deleted.

Examples:

- penyakit (IL) > panaki (ML) 'disease'

- syahadat (IL) > sahadha (ML) 'witness'

- kunyit (IL) > kuni (ML) 'turmeric'

- minyak (IL) > mina (ML) 'oil'

- payung (IL) > pau (ML) 'umbrella'

- $\operatorname{syarat}(\mathrm{IL})>$ sarati (ML) "criteria"

- syukur (IL) > sukuru (ML) "thank"

- syariat (IL) > sariati (ML) "religion law"

- rakyat $(\mathrm{IL})>$ raeati $(\mathrm{ML})$ 'people'

- buaya (IL) > buea (ML) 'crocodile'

The phenomenon is the same as the above explanation, in which native speakers of Muna usually adopt and adapt loan words into Muna sound features. Related to the addition of vowel, it is adapted to the closed sound feature of a preceded vowel. It occurs because the speakers tend to easier to pronounce it if the vowels in one word have similar or rather similar sound features.

\section{Deletion of a Sound on the Final Position}

Consonants $/ k /, / n /$, and $/ \eta /$ on the final position

When consonants $/ \mathrm{k} /, / \mathrm{n} /$, and $/ \mathrm{n} /$ consist of more than one syllable and on the final position of Indonesian word, the consonants $/ \mathrm{k} /, / \mathrm{n} /$, and $/ \mathrm{y} /$ in Muna 
language are deleted, but if the Indonesian words end with consonants $/ \mathrm{k} /$ and $/ \mathrm{n} /$ consist of one syllable on the final position, the consonants $/ \mathrm{k} /$ and $/ \mathrm{n} /$ in Muna language are added with vowel /i/.

Examples:

- $\operatorname{anak}$ (IL) > ana (ML) 'child'

- badik (IL) > bhadi (ML) 'machete'

- bapak (IL) > bapa (ML) 'father'

- bebek (IL) > bebe (ML) 'duck'

- belok (IL) > belo (ML) 'turn'

- handuk (IL) > handu (ML) 'towel'

- kubik (IL) > kubi (ML) 'cubic meter'

- nenek (IL) > nene (ML) 'grand mother'

- bensin (IL) > bensi (ML) 'gasoline'

- bidan (IL) > bida (ML) 'midwife'

- dosen (IL) > dose (ML) 'lecturer'

- pelabuhan (IL) > pelabuha (ML) 'port'

- undangan (IL) > undanga (ML) 'invitation'

- empang (IL) > empa (ML) 'pond'

- ledeng (IL) > lede (ML) 'tap-water'

- pimpong (IL) > pimpo (ML) 'pimpong'

- piring (IL) > piri (ML) 'plate'

- ban (IL) > bani (ML) 'tire'

- pen (IL) > peni (ML) 'point'

- $\operatorname{bak}(\mathrm{IL})>$ baki (ML) 'tub'

- $\operatorname{rak}(\mathrm{IL})>\operatorname{raki}(\mathrm{ML})$ 'rack'

Muna's speaker is very difficult to pronounce the consonant sounds in the final position because they are used to the Muna language which does not have consonant sounds at the end of a word. In other words, they are easier to pronounce vowel sounds or vocoid either in the middle or final position.

\section{Addition of Vowel Phoneme}

The addition of sound in this study is the addition of vowels to delete all consonant sounds on the final position because Muna language is categorized as vocalist language. Based on data found in the field, the addition of vowel phoneme on Indonesian loan words in Muna language can be divided into two groups: (1) addition of vowel in the middle position, and (2) addition of vowel in the final position.

\section{Addition of Vowel in the Middle Position}

Muna language is categorized as vocalist language, so loan words from the Indonesian language have cluster/sequences consonants. A vowel inserts the cluster of consonant sequences to create an open syllable.

\section{Consonant Phonemes /b/, /k/, and / $/ p /$}

Indonesian loan words on the middle position syllable in which one of the particular consonants such as $/ \mathrm{b} /, / \mathrm{k} /$, and $/ \mathrm{p} /$ is followed by other consonant and preceded by vowel /a/, in the Muna language the consonants $/ \mathrm{b} /, / \mathrm{k} /$, and $/ \mathrm{p} /$ are inserted with vowel $/ \mathrm{u} /$. In other words, the vowel $/ \mathrm{u} / \mathrm{is}$ inserted to separate these two consonants.

Examples:

- bakso (IL) > bakuso (ML) 'meatball'

- bakteri (IL) > bakuteri (ML) 'bacteria'

- kapten (IL) > kaputeni (ML) 'captain'

- karakter (IL) > karakuteri (ML) 'character'

- pabrik (IL) > fabureki (ML) 'facture'

- sabtu (IL) > saputu (ML) 'Saturday'

- saksi (IL) > sakusi (ML) 'witness'

- takbir (IL) > takubiru (ML) 'takbir'

- taksir (IL) > takusere (ML) 'appraisal'

- taksi (IL) > takusi (ML) 'taxi'

- traktor (IL) > tarakutoro (ML) 'tractor'

- waktu (IL) > wakutu (ML) 'time' 
The addition of vowels of loan words which are usually done by Muna native speakers is not separated by the factor of the ease in pronunciation. Like the deletion of consonants and breaking the opened syllable to closed syllable, the addition of vowel occurred because the Muna native speaker habitual to use vowel sound in the end or final position either in the middle or at the end of a word. It lines to the Schane's and Crowley's statements or theories of harmony vowel that one vowel usually assimilated to other vowel features (Crowley, 1992; Schane, 1973) It occurs because the speakers tend to easier to pronounce it if the vowels in one word have similar or rather similar sound features. Other phenomena below either addition of vowel in the middle or final position refer to this explanation as stated by (Aso, 2006; Crowley, 1992; Schane, 1973).

\section{Consonant Phoneme /s/}

Loan words from the Indonesian language, which consists of consonant /s/ and followed by other consonants and preceded or followed by vowel /a/ on the middle position syllable, in the Muna language the consonant $/ \mathrm{s} /$ is inserted with vowel /i/. In other words, the insertion of vowel /i/ after the consonant /s/ in Muna language is to separate consonant /s/ and other consonants.

Examples:

- aspal (IL) > asipalu (ML) 'asphalt'

- pasti (IL) > pasiti (ML) 'sure'

- pastor (IL) > pasitoro (ML) 'pastor'

- paksa (IL) > pakisa (ML) 'force'

- masker (IL) > masikere (IL) 'mask

- plastik (IL)> palasiti (ML) 'plastic'

- kasta (IL) > kasita (ML) 'caste'

- kastik (IL) > kasiti (ML) 'baseball'

\section{Consonant Phoneme / $r /$}

When 1 the loan words from the Indonesian language consist of consonant $/ \mathrm{r} /$ and other consonants on the middle position syllable, in Muna language the consonant $/ \mathrm{r} /$ is inserted with a vowel-like vowel before the consonant $/ \mathrm{r} /$ to separate the consonant /r/ with other consonants.

Examples:

- garpu (IL) > garapu (ML) 'spoon'

- harga (IL) > haraga (ML) 'price'

- harta (IL) > harata (ML) 'treasure'

- kursi (IL) > kurusi (ML) 'chair'

- parkir (IL) > parakiri (ML) 'parking'

- $\operatorname{surga}(\mathrm{IL})>\operatorname{suruga}(\mathrm{ML})$ 'heaven'

- $\operatorname{warga}(\mathrm{IL})>$ waraga (ML) 'society'

- warna (IL) > warana (ML) 'color'

Addition of Vowel on the Final Position Consonant /b/, /f/, /l/, /m/, /p/, and $/ \mathrm{s} /$ on the Final Position

Loan words from Indonesian language which end with certain consonant such as consonant /b/, /f/, /l/, $/ \mathrm{m} /, / \mathrm{p} /$, and $/ \mathrm{s} /$ on the final position which preceded by vowel /a/, /e/ or /o/ after consonants $/ \mathrm{b} /, / \mathrm{f} / / \mathrm{l} / \mathrm{,} / \mathrm{m} /, / \mathrm{p} /$, and $/ \mathrm{s} /$ in Muna language are added with vowel /u/. However, if Indonesian words end with consonant $/ \mathrm{l} /$ and the words more than one syllable, the consonant /1/ in Muna language is added with the vowel like the vowel before consonant $/ 1 /$.

Examples:

- jilbab (IL) > jilibabu (ML) 'veil'

- $\operatorname{arab}$ (IL) > arabu (ML) 'arabic'

- maaf (IL) > maafu (ML) 'sorry'

- insaf (IL) > insafu (ML) 'aware'

- nol (IL) > nolu (ML) 'zero'

- $\operatorname{rol}(\mathrm{IL})>\operatorname{rolu}(\mathrm{ML})$ 'roll'

- $k o l$ (IL) > kolu (ML) 'cabbage'

- $w o l$ (IL) > wolu (ML) 'wool' 
- $\quad$ bom (IL) > bomu (ML) 'boom'

- atom (IL) > atomu (ML) 'atom'

- helm (IL) > helemu (ML) 'helmet'

- $\operatorname{rem}(\mathrm{IL})>$ remu (ML) 'brake'

- $\operatorname{lem}(\mathrm{IL})>$ lemu (ML) 'glue'

- $\quad l a p(\mathrm{IL})>$ lapu (ML) 'rag'

- bos (IL) > bosu (ML) 'boss/leader'

- $p o s(\mathrm{IL})>$ posu (ML) 'post'

- bangsal (IL) > bhansala (ML) 'ward'

- $\operatorname{ramal}(\mathrm{IL})>$ ramala $(\mathrm{ML})$ 'predict'

- batal (IL) > batala (ML) 'cancel'

- hafal (IL) > hafala (ML) 'to memorize'

- fatal (IL) > fatala (ML) 'outrageous'

- kapal (IL) > kapala (ML) 'ship'

Consonant $/ s /$ and $/ t /$ on the Final Position

Loan words from the Indonesian language which end with consonants /s/ and $/ \mathrm{t} /$ and the consonant $/ \mathrm{s} /$ and $/ \mathrm{t} /$ are preceded by vocal $/ a /$, in Muna language the consonant $/ \mathrm{s} /$ and $/ \mathrm{t} /$ is added with vowel /i/.

Examples:

- awas (IL) > awasi (ML) 'look after'

- bahas (IL) > bahasi (ML) 'discuss'

- batas (IL) > batasi (ML) 'border'

- gas (IL) > gasi (ML) 'gas'

- las (IL) > lasi (ML) 'to weld'

- malas (IL) > malasi (ML) 'lazy'

- pas (IL) > pasi (ML) 'fit/suitable'

- rampas (IL) > rampasi (ML) 'loot'

- $\operatorname{tas}$ (IL) > tasi (ML) 'bag'

- tugas (IL) > tugasi (ML) 'task'

- ibarat (IL) > ibarati (ML) 'like'

- alamat (IL) > alamati (ML) 'address'

- bakat (IL) > bakati(ML) 'talent'

- tamat (IL) > tamati (ML) 'end'

- rahmat (IL) > rahamati $(\mathrm{ML})$ 'grace'
- niat (IL) > niati (ML) 'intention'

- pangkat (IL) > pangkati (ML) 'rank'

- rapat (IL) > rapati (ML) 'close together/meeting'

- $\quad$ ketat (IL) > ketati (ML) 'strict'

- $\operatorname{sikat}(\mathrm{IL})>$ sikati (ML) 'brush'

\section{Consonant / $r$ / on the Final Position}

Loan words from the Indonesian language, which end with consonant $/ \mathrm{r} /$ on the final position, the consonant $/ \mathrm{r} /$ in Muna language is added with a vowellike a vowel before consonant $/ \mathrm{r} /$. Examples:

- anggur (IL) > angguru (ML) 'grape/wine'

- bongkar (IL) > bhongkara (ML) 'unloading'

- ember (IL) > embere (ML) 'bucker'

- gambar (IL) > gambara (ML) 'picture'

- honor (IL) > honoro (ML) 'honor'

- kabar (IL) > kabara (ML) 'news'

- liter (IL) > litere (ML) 'liter'

- mahar (IL) > mahara (ML) 'dowry'

- nomor (IL) > nomoro (ML) 'number'

- $\operatorname{per}(\mathrm{IL})>$ pere $(\mathrm{ML})$ 'per'

- $\operatorname{sihir}$ (IL) > sihiri (ML) 'black magic'

- tambur (IL) > tamburu (ML) 'European drum'

- bubur (IL) > buburu (ML) 'porridge'

\section{CONCLUSION}

Muna language characteristics as vocalist language bring all loan words from other languages, especially Indonesian language in Muna language always become open syllable. It occurs both by adding and missing consonants and adding and breaking clusters. This study focuses on several sound changes 
of loan words. First, consonant /k/, /n/, and $/ \mathrm{y} /$ on the final position of Indonesian word are deleted when they are borrowed/used in the Muna language; and consonant $/ \mathrm{y} / \mathrm{m}$ Indonesian word is deleted when it is borrowed/used in Muna language, especially in cluster or sequence sounds of consonants. Second, loan words from Indonesian language which end with certain consonant such as consonants $/ \mathrm{b} /$, $/ \mathrm{k} /$, and $/ \mathrm{p} /$ if they are followed by other consonants on the middle position syllable, the consonants $/ \mathrm{b} /, / \mathrm{k} /$, and $/ \mathrm{p} /$ are inserted with vowel $/ \mathrm{u} /$ to separate the consonants $/ \mathrm{p} /, / \mathrm{b} /$, and $/ \mathrm{k} /$ with other consonants. Third, loan words from the Indonesian language consisting of consonant /s/ and other consonants on the middle position syllable, the consonant /s/ in Muna language is inserted with vowel /i/ to separate the consonant /s/ with other consonants. Forth, loan words from the Indonesian language, which end with consonant $/ \mathrm{r} /$ and the consonant $/ \mathrm{r} /$ is followed by other consonants on the middle position syllable, in Muna language, the consonant $/ \mathrm{r} /$ is inserted with a vowellike vowel in front of the consonant $/ \mathrm{r} /$. Fifth, loan words from Indonesian language which end with consonants $/ \mathrm{b} /$, $/ \mathrm{f} /, / \mathrm{l} /, / \mathrm{m} /$ and $/ \mathrm{p} /$ on the final position which preceded by vowel /a/, the consonants $/ \mathrm{b} /, / \mathrm{f} /, / 1 /, / \mathrm{m} /$ and $/ \mathrm{p} /$ are inserted with vowel /u/. Sixth, loan words from Indonesian language which end with consonant / $/$ / and /s/ on the final position which preceded by vowel $/ \mathrm{a} /$, the consonant $/ \mathrm{t} /$ and $/ \mathrm{s} /$ in Muna language is added with vowel /i/. Seventh, When the Indonesian loan words end with consonant $/ \mathrm{r} /$ on the final position, the consonant $/ \mathrm{r} /$ in the Muna language is added with a vowel-like vowel in front of the consonant $/ \mathrm{r} /$.

The seven linguistics phenomena above occur because Muna language is a vocalist language and its native speakers are very difficult to pronounce consonant sounds at an opened position or open syllable. Therefore, native speakers of Muna usually adopt and adapt loan words into Muna sound features. The speakers tend to ease the pronunciation if the vowels in one word have similar or rather similar sound features. Muna's speaker is very difficult to pronounce the consonant sounds in the final position because they are used to Muna language which does not have consonant sounds in the opened syllable. However, this study is limited to some areas of Muna language speakers in Southeast Sulawesi i.e. Kendari and Raha.

Symbol and Abbreviations:

$>\quad=$ become

IL = Indonesian Language

ML = Muna Language

\section{REFERENCES}

Aso, L. (2006). Inovasi internal dalam bahasa Muna dan perlakuan katakata serapan dari bahasa Indonesia. In. Yogyakarta: Universitas Gadjah Mada.

Bronstein, A. J., \& Beatrice, F. J. (1967). Your speech and sound. New York: Random House.

Campbell, L. (1998). Historical linguistics: Edinburgh University Press.

Chaer, A. (2003). Linguistik umum. Jakarta: Rineka Cipta.

Crowley, T. (1992). An Introduction to historical linguistics (1 ed.). UK: Oxford University Press.

Finegan, E. (2014). Language: Its structure and use. London: Cengage Learning.

Gleason, J. H. A. (1961). An introduction to descriptive linguistics. New York: Holt, Rinehart, and Winston. 
Irmawati, I. (2004). Inflectional affixes of verb in Tolaki language of Konawe dialect. In. Kendari: Universitas Haluoleo.

Mahsun, M. S. (1995). Dialektologi diakronis: Sebuah pengantar: Gadjah Mada University Press.

Malmberg, B. (1961). Fonetics. New York: Dover Publications.

Marsono, M. (1986). Fonetik. Yogyakarta: Universitas Gadjah Mada Press.

Oxford Learner's Dictionaries. (2017). Oxford learner's dictionaries. Retrieved from www.oxfordlearnersdictionaries. com.

Robins, R. H. (1992). Linguistik umum. In. Yogyakarta: Kanisius.

Schane, S. A. (1973). Generative phonology. New Jersey: Pretice hall Inc.
Sudaryanto. (1993). Metode dan aneka teknik analisis bahasa: Pengantar penelitian wahana kebudayaan secara linguistis: Duta Wacana University Press.

Taembo, M. (2013). Studi perbandingan bahasa Muna dan Wakatobi di Sulawesi Tenggara (Tinjauan sinkronis dan diakronis). Yogyakarta: Universitas Gadjah Mada.

Van den Berg, R. (1989). A grammar of the Muna language (Vol. 139): Foris Publications Dordrecht, The Netherlands.

Van den Berg, R. (1995). Forestry, injections and cards: Dutch loans in Muna. Tales from a concave world. Liber amicorum Bert Voorhoeve, 191-215.

Vervaet, R. (2017). English loanwords in the Chinese lexicon. MA Thesis, Universiteit Gent, Gent, Belgium. 